\title{
EDITORIAL
}

\section{PESCO - MORE SECURITY FOR EUROPE}

The end of this year, more precisely 13 December, will mark the first anniversary of the initiation of PESCO. The acronym PESCO refers to Permanent Structured Cooperation.

The objective of PESCO is to deepen defence cooperation of EU Member States (EU) in the development of common defence capabilities, joint projects and operational readiness as well as military contribution.

In its early beginnings, the EU devoted most of its attention to the economic progress of its member states, which was a very logical goal in the decade following the end of World War II. Later on, the rudiments of security and defence appeared in the form of the Western European Union, Common Foreign and Security Policy and the like. Until the start of war in the former Yugoslavia, the EU did not have a serious need or reason to particularly focus on security. Security policy was just one of the policies that had mainly been present on paper and in various debates. This became particularly obvious in the case of the intensive developments in the Balkans. This case very well tested the functioning of the EU and revealed the need for fundamental changes. One of the results was also an increased engagement in the field of international operations and missions: an observation mission in Georgia, a police and the rule of law mission in Kosovo, mission to assist in the aftermath of a tsunami in Indonesia, a counter-piracy mission in Somalia, and a mission protecting refugees in Mali.

The second key milestone in the EU's security and defence engagement was the European migration crisis in 2015. Here, the lack of appropriate policies at the EU level became most evident. More precisely, it revealed the contradictory application of the policies within the EU to member states and their citizens, and to those other countries and their inhabitants who do not benefit from the high values, ethical standards and social advantages when they arrive in unimaginably large numbers. 
Before the important EU bodies met, consulted, decided and acted, many problems in different areas had been identified. One of the key issues was the security problem.

However, there were still many other influences that gave rise to the creation of PESCO. They are discussed by the authors in this issue. Nevertheless, let me just mention that the EU has in some way found itself at a turning point due to the increasingly present Euroscepticism, which was also discussed at this year's Strategic Forum at Bled.

In their article PESCO - on the way to a European security and defence union or another dead end? Petra Culetto and Jure Himerajh try to establish whether or not PESCO will become a success story. The authors argue that the main purpose of PESCO is to further integrate and deepen the security and defence cooperation. What will be its future and the role of Slovenia in it?

Strategy and military deterrence capabilities is the title of the article by Anže Rode, in which he examines the strategic changes in the security environment, new forms of threats and the positioning of small countries in securing their defence against bigger ones. After all, in the international alliances, the position of big countries is slightly different. Therefore, the author proposes several initiatives for Slovenia and the Slovenian Armed Forces.

In their article Modernization within the Hungarian Armed Forces József Padányi and László Földi write about the changes in the international security environment. They find that the modernization of equipment and technology in the armed forces is important. It is therefore necessary to keep abreast of the times, provide for the security of individuals, their country, and perform one's role in the Alliance.

The 2017 Capability Targets of the Slovenian Armed Forces foresee the generation of medium infantry battalion groups with vehicles fitted with $30 \mathrm{~mm}$ cannons, says Viktor Potočnik in his article Armoured personnel carrier or infantry fighting vehicle in a medium infantry battalion group. According to the author, this opens a few unknowns, which are defined in the article. What is more, the author even provides some solutions.

Jihadism and radicalisation in selected regions of Europe, the Middle East and North Africa - a case study is the article by József Kis-Benedek. It emerges from the trends of the last two years, when the citizens of various European countries have been actively engaging in the fights in Syria and have been returning from these fights back to their countries. What does this mean for their native countries securitywise? The author shares some interesting and different viewpoints.

Security trends demand changes in several areas, and the field of security changes in itself. Usually, changes happen too slowly, but the field of security is a sensitive one 
and the changes need to be well thought out, perfectly written and comprehensively organized. It is therefore important that scientists and experts, both civilian and military, exchange their experiences, views and ideas about security in the future. One of the options to do that is our publication.

You are most welcome to read and write! 